\title{
Effects of amount of colostrum replacer, amount of milk replacer, and housing cleanliness on health, growth, and intake of Holstein calves to 8 weeks of age
}

\author{
J. D. Quigley, ${ }^{1}$ T. M. Hill, L. L. Deikun, and R. L. Schlotterbeck \\ Nurture Research Center, Provimi, Brookville, OH 45309
}

\begin{abstract}
Newborn Holstein bull calves $(\mathrm{n}=96)$ were assigned randomly at birth to receive $150 \mathrm{~g}$ (C150) or $450 \mathrm{~g}$ (C450) of IgG in the first $24 \mathrm{~h}$ of life from a lacteal-based colostrum replacer in 2 trials. Mass of product fed was 500 and 1,500 g, respectively. Replacer was reconstituted with warm water and administered by esophageal feeder at approximately 1,6 , and $12 \mathrm{~h}$ of age. Thereafter, calves were fed $2 \mathrm{~L}$ of whole milk twice daily at approximately 0700 and $1700 \mathrm{~h}$ until transported to the experimental facility at 2 to $3 \mathrm{~d}$ of age. Calves fed C450 had greater serum total protein and IgG concentrations at 2 to $3 \mathrm{~d}$ of age. Failure of passive transfer of immunity (serum $\operatorname{IgG}<10 \mathrm{~g} / \mathrm{L}$ ) was detected in 100 and $11 \%$ of calves fed C150 and C450, respectively. Calves $(\mathrm{n}=48)$ in trial 1 were assigned randomly within colostrum group to receive $0.68 \mathrm{~kg} / \mathrm{d}$ of milk replacer (MR) for $42 \mathrm{~d}$, and then $0.34 \mathrm{~kg} / \mathrm{d}$ for $7 \mathrm{~d}$ (moderate $\mathrm{MR}$, MMR) or $1 \mathrm{~kg} / \mathrm{d}$ of MR for $5 \mathrm{~d}, 1.36 \mathrm{~kg} / \mathrm{d}$ for $37 \mathrm{~d}$, and $0.68 \mathrm{~kg} / \mathrm{d}$ for $7 \mathrm{~d}$ (high MR, HMR). Starter and water were available for ad libitum consumption. Calves fed HMR had greater average daily gain, higher average fecal scores, more days with abnormal fecal scores, and more medical days than calves fed MMR. Calves fed HMR also had lower starter intake and tended to have lower gain-to-feed ratio than calves fed MMR. Calves fed C450 and MMR began eating calf starter earlier and ate more starter than other groups from 3 wk. In trial 2 , calves $(\mathrm{n}=48)$ were assigned randomly within colostrum group to housing in nursery pens bedded with clean, dry straw (clean bedding) or soiled straw used in previous studies (dirty bedding). Milk replacer was fed at $0.68 \mathrm{~kg} / \mathrm{d}$ for $39 \mathrm{~d}$, and then $0.34 \mathrm{~kg} / \mathrm{d}$ for 3 $\mathrm{d}$ along with free-choice texturized starter and water. Calves fed C450 had fewer days with abnormal fecal scores and days with medical treatments compared
\end{abstract}

Received February 22, 2017.

Accepted August 1, 2017.

${ }^{1}$ Corresponding author: jquigley@provimi-na.com with calves fed C150. Calves housed in dirty bedding tended to grow more slowly and have lower gain-to-feed ratio than calves housed with clean bedding. Temporal changes in serum IgG and total protein varied by treatment. Serum IgG in calves fed C150 varied little from 0 to 4 wk and increased thereafter, whereas IgG in calves fed C450 declined to $4 \mathrm{wk}$ (estimated half-life $=23.9$ d) and increased thereafter. Differences in serum IgG concentrations caused by feeding different amounts of colostrum replacer did not markedly affect growth or intake when calves were fed different amounts of milk replacer or when they were housed with clean or dirty bedding.

Key words: calves, colostrum, disease, growth

\section{INTRODUCTION}

Health of young dairy calves has an important effect on preweaning performance and, possibly, on production later in life (Weaver et al., 2000; Heinrichs and Heinrichs, 2011; Soberon et al., 2012). Early consumption of an adequate amount of high-quality colostrum is important for acquisition of passive immunity, which, in turn, may influence predisposition to disease (Donovan et al., 1998; Weaver et al., 2000; Stilwell and Carvalho, 2011).

When colostrum is of inadequate quantity or quality to feed the newborn calf, colostrum supplement or replacer products may be used. Such products vary in IgG source (plasma, colostrum), nutrient composition, and the ability of the calf to absorb IgG from the product (Quigley et al., 2002; Foster et al., 2006; Swan et al., 2007).

Some studies have reported that calves fed colostrum products may be more or less predisposed to infectious diseases such as diarrhea during the critical first weeks of life (Jones et al., 2004; Swan et al., 2007). Also, the environment in which the animal is raised may influence predisposition to disease (Frank and Kaneene, 1993; Gulliksen et al., 2009; Cobb et al., 2014) or animal performance (Hill et al., 2011). Important interactions 
may exist between passive immunity, nutrition, and environment. For example, calves with different passive immune status may utilize nutrients differently when fed varying amounts of liquid preweaning (Hill et al., 2006; Quigley et al., 2006). Also, even though it has been shown that the level of liquid fed before weaning has a positive effect on preweaning growth (e.g., Khan et al., 2011), potential interactions of feeding level and immune status are not clear. Alternatively, calves may be more predisposed to disease when housed in environments with greater immunological challenge. Therefore, our hypothesis was that passive immunity as a result of variable colostrum replacer ingestion and either nutrient supply by different liquid feeding or pen cleanliness would not affect measurements of growth, feed efficiency, or health of calves to $56 \mathrm{~d}$ of age.

\section{MATERIALS AND METHODS}

\section{Colostrum Feeding}

Newborn Holstein bull calves $(\mathrm{n}=96)$ were used in 2 studies of 48 calves. Trial 1 was conducted between September 18 and November 13, 2013, and trial 2 was conducted between November 21, 2013 and January 22, 2014.

All calvings were observed. Within $1 \mathrm{~h}$ of birth, each calf was moved from the maternity pen to a clean plastic hutch bedded with straw. Heat lamps were used during cold weather. Each calf was identified with an ear tag and then assigned randomly to receive a total of $150 \mathrm{~g}(\mathbf{C 1 5 0})$ or $450 \mathrm{~g}(\mathbf{C 4 5 0})$ of IgG from a colostrum replacer product (Genesis 150, Provimi, Brookville, $\mathrm{OH}$; Table 1) at approximately 1, 6, and $12 \mathrm{~h}$ of age. The replacer product contained $30 \%$ IgG derived from bovine colostrum. The masses of powder fed, respectively, for C150 and C450, were 167 and 500 $\mathrm{g} /$ feeding, and powder was reconstituted to approximately $13 \%$ solids with warm water. Reconstituted liquid was administered by esophageal feeder. After 24 $\mathrm{h}$, calves were moved to individual hutches and fed 2

Table 1. Composition (\% of DM unless otherwise noted) of colostrum replacer $(\mathrm{CR})$, milk replacer $(\mathrm{MR})$, and starter in trials 1 and 2

\begin{tabular}{lccccccc}
\hline & \multicolumn{3}{c}{ Trial 1 } & & \multicolumn{3}{c}{ Trial 2 } \\
\cline { 2 - 4 } \cline { 6 - 8 } Nutrient & CR & MR & Starter & & CR & MR & Starter \\
\hline DM, \% & 94.3 & 96.1 & 88.4 & & 94.7 & 96.3 & 88.0 \\
CP & 47.3 & 27.4 & 20.9 & & 47.2 & 27.5 & 20.8 \\
Fat & 19.5 & 17.9 & 3.6 & & 19.7 & 17.8 & 3.8 \\
ADF & - & - & 5.8 & & - & - & 5.9 \\
NDF & - & - & 12.5 & & - & - & 12.8 \\
Ash & - & 4.6 & 7.3 & & - & 4.7 & 7.2 \\
\hline
\end{tabular}

L of whole milk twice daily in individual nipple bottles until transported approximately $3.5 \mathrm{~h}$ on a truck to the experimental facility at 2 to $3 \mathrm{~d}$ of age.

Trial 1. On arrival, calves were assigned randomly within colostrum group to receive a milk replacer (MR; $26 \%$ CP, $17 \%$ fat, as-fed basis; Table 1) containing whey, whey protein concentrate, dry fat, vitamins, and minerals at the following rates: $0.68 \mathrm{~kg} / \mathrm{d}$ to 42 $\mathrm{d}$ and then $0.34 \mathrm{~kg} / \mathrm{d}$ for $7 \mathrm{~d}$ (moderate, MMR) or $1.0 \mathrm{~kg} / \mathrm{d}$ of MR for $5 \mathrm{~d}, 1.36 \mathrm{~kg} / \mathrm{d}$ for $37 \mathrm{~d}$, and then $0.68 \mathrm{~kg} / \mathrm{d}$ for $7 \mathrm{~d}$ (high, HMR). Milk replacer was reconstituted to 13 and $15 \%$ solids, respectively, for MMR and HMR treatments and fed at 0600 and 1530 $\mathrm{h}$ in nipple buckets. A texturized starter $(18 \% \mathrm{CP}, 3.0$ Mcal of ME $/ \mathrm{kg}$ as fed) and water were available at all times. Starter refusals were measured daily and new starter was offered at $1100 \mathrm{~h}$. Average temperature in the nursery was $5^{\circ} \mathrm{C}\left(-9\right.$ to $\left.22^{\circ} \mathrm{C}\right)$ and average relative humidity was $70 \%$ (29 to 100\%).

Trial 2. Pens were bedded with deep straw according to normal management for the farm, but straw was either clean and unused (clean bedding, $\mathbf{C B}$; $\mathrm{n}=24$ ) or soiled (dirty bedding, DB; $\mathrm{n}=24$ ). Soiled straw bedding was collected during a previous trial and stored in an open-sided, unheated shed. No effort was made to standardize or quantify the degree of contamination in soiled bedding; however, soiled bedding selected for use as bedding in this trial was visibly wet, contained fecal material from calves in the previous study, or both. On arrival, calves were assigned randomly within colostrum group to CB or DB treatments. Bedding was replaced as needed with clean or soiled bedding. Calves were fed $0.68 \mathrm{~kg}$ of a $26 \% \mathrm{CP}, 17 \%$ fat (as-fed basis) MR (Table 1) containing whey, whey protein concentrate, dry fat, vitamins, and minerals and diluted to $13 \%$ solids for $39 \mathrm{~d}$ in 2 equal meals, and then once daily for $3 \mathrm{~d}$. A texturized starter $(18 \% \mathrm{CP}, 3.0 \mathrm{Mcal}$ of $\mathrm{ME} / \mathrm{kg}$ as fed; Table 1) and water were available at all times. The average temperature in the nursery was $-3^{\circ} \mathrm{C}$ with a range from -24 to $21^{\circ} \mathrm{C}$. The average relative humidity was $74 \%$ with a range from 38 to $100 \%$.

\section{General Management}

Calves were cared for under acceptable practices as described in the Guide for the Care and Use of Agricultural Animals in Research and Teaching (FASS, 2010). Upon arrival at the experimental facility, calves were unloaded, placed into individual pens, and assigned randomly within colostrum group to treatment. Calves were fed $2 \mathrm{~L}$ of electrolytes at the p.m. feeding. At $1100 \mathrm{~h}$ on the day after arrival, calves were weighed (initial BW), blood was sampled from the jugular vein, serum was harvested, and serum total protein (TP) 
concentration was immediately measured using an optical refractometer (Atago U.S.A. Inc., Bellevue, WA). A sample of serum was frozen $\left(-20^{\circ} \mathrm{C}\right)$ before analysis of $\mathrm{IgG}$ by radial immunodiffusion (Triple $\mathrm{J}$ Farms, Bellevue, WA). Apparent efficiency of IgG absorption (AEA) was calculated as described by Quigley et al. (1998). In trial 2, blood samples were collected by jugular venipuncture at weekly intervals for determination of serum TP and IgG.

In both trials, calves were housed in $1.2-\times 2.4-\mathrm{m}$ individual pens within a curtain sidewall barn with no added heat. Calves received an intranasal tissue sensitive respiratory disease vaccine (TSV-2, Pfizer, Exton, PA) and subcutaneous injections of vitamins A, D, E (Vital E-A + D, Schering-Plough Animal Health, Union, NJ) and Se (MU-SE, Schering-Plough Animal Health) upon arrival. Calves received an injection of Bovashield Gold 5 (Pfizer) at d 7 and again at d 28 . Calves were castrated and dehorned at $39 \mathrm{~d}$ of age. Meloxicam was administered $(1 \mathrm{mg} / \mathrm{kg}$ of $\mathrm{BW})$ approximately $6 \mathrm{~h}$ before castration and dehorning. All medical treatments and protocols were under supervision of a veterinarian and were based on scouring (fecal scores $>2$ ), lethargy, elevated rectal temperatures, and rapid breathing.

Each bag of MR and starter were sampled and composited before initiation of each trial. Composites were analyzed (AOAC International, 2000) for DM (oven method 930.15), CP (Kjeldahl method 988.05), and fat (alkaline treatment with Röse-Gottlieb method 932.06 for MR; diethyl ether extraction method 2003.05 for starters). Additionally, starters were analyzed for NDF with ash by the procedure of Van Soest et al. (1991) without sodium sulfite or $\alpha$-amylase, and ADF with ash (Robertson and Van Soest, 1981). Composition of colostrum replacer was provided by the manufacturer before initiation of the trials.

Calves were weighed on arrival and every $7 \mathrm{~d}$ thereafter until the end of each trial (d 56). Dry feed offered and feed refusals were weighed daily. Fecal scores were assigned daily based on a 1 to 5 system $(1=$ normal, thick in consistency; $2=$ normal, but less thick; 3 $=$ abnormally thin but not watery; $4=$ watery; $5=$ watery with abnormal coloring; modified from Kertz and Chester-Jones, 2004). Medical treatments were recorded daily. Hip widths were measured with a caliper, and BCS of calves were measured at d 0 and every $14 \mathrm{~d}$ thereafter. A 1 to 5 scale with 0.25 -unit increments was used (1, emaciated to 5, obese) based on a modification from Wildman et al. (1982). Scores were based on changes around the vertical and transverse processes of the spine as palpated by one experienced technician and ranged from 1.5 to 3.5 .

\section{Statistical Analysis}

Sample size was calculated based on the experience of previous studies (Chapman et al., 2016, 2017) using similar procedures at the same facility and expecting a $90 \%$ probability to detect a $\leq 200 \mathrm{~g} / \mathrm{d}$ difference in ADG with SE of $100 \mathrm{~g} / \mathrm{d}$ at $P<0.05$. Data were analyzed using the MIXED procedure in SAS (version 9, SAS Institute Inc., Cary, NC). Serum TP and IgG, AEA, and percent of calves with failure of passive transfer (FPT; serum IgG $<10 \mathrm{~g} / \mathrm{L}$ ) in calves from both trials were analyzed as a $2 \times 2$ factorial arrangement of $\operatorname{IgG}$ intake and trial. All other data were analyzed as a $2 \times$ 2 factorial arrangement of colostrum program and MR feeding level (trial 1) or pen cleanliness (trial 2) in a completely randomized design. Animal was included as a random variable. For data measured weekly or every $2 \mathrm{wk}$, a repeated-measures analysis was conducted with week and treatment $\times$ week included in each model. Error was estimated using Kenward-Roger procedures for determining degrees of freedom. A large difference existed among initial BW in trial 1. Initial BW were $36.3,38.8,46.2$, and $44.9 \mathrm{~kg}(\mathrm{SE}=1.19)$. To reduce effects of initial BW on other measures in trial 1, data were reanalyzed using initial $\mathrm{BW}$ as a covariable in the mixed model ANOVA. All data are reported as least squares means and covariate-adjusted least squares means are reported for trial 1. Experimental unit was calf. Analysis of percent morbidity and percent FPT were conducted by logistic regression using the Logistic procedure of SAS. Statistical differences are discussed at $P \leq 0.05$, and trends are mentioned when $P \leq 0.10$. Variances of LSM did not differ among treatments groups; therefore, pooled SEM are presented.

\section{RESULTS}

\section{Overall Serum IgG and TP}

Serum IgG and TP (Table 2) indicated that calves fed C450 absorbed more IgG than calves fed C150. Serum TP was markedly lower for both treatments in trial 2 , although IgG concentrations were unaffected. We detected no effect of treatment or trial on AEA, which averaged $13 \%$. All calves fed C150 were diagnosed with FPT, whereas $21 \%$ of calves $(n=5)$ fed C450 in trial 1 and no calves in trial 2 were diagnosed with FPT.

\section{Performance and Health}

Trial 1. Although calves were assigned randomly within colostrum group to MR treatments, calves on the HMR treatment were larger (BW, initial hip width, initial BCS) at initiation of the trial (Table 3). Calves 
Table 2. Serum total protein (TP), serum IgG, apparent efficiency of absorption (AEA), and percent of calves with failure of passive transfer (FPT) in calves fed $150(\mathrm{C} 150)$ or $450(\mathrm{C} 450) \mathrm{g}$ of $\mathrm{IgG}$ in the first $24 \mathrm{~h}$ in trials 1 and 2

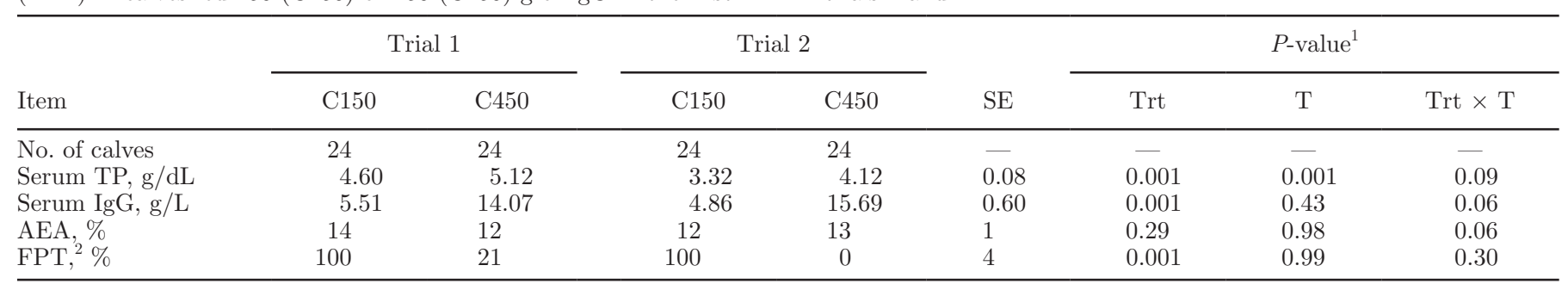

${ }^{1}$ Probability of a significant effect of treatment (Trt), trial $(\mathrm{T})$, or their interaction $($ Trt $\times \mathrm{T})$.

${ }^{2}$ Analyzed by logistic regression.

fed HMR had greater final BW, hip width, and ADG, and tended to have greater hip width change, fecal scores, and more medical days than calves fed MMR. Calves fed HMR had lower starter intake. Change in BCS did not differ between feeding rates. No mortality occurred during the trial.

Body weight (Figure 1), starter intake (Figure 2), ADG (Figure 3), feed efficiency (gain-to-feed ratio; Figure 4), BCS change, and hip width change were affected by week $\times$ treatment interactions. Calves fed MMR consumed more starter and calves fed MMRC450 consumed more starter from approximately 4 wk of age than other treatments. Calves fed HMR had greater ADG to weaning; thereafter, ADG was less than for calves fed MMR. Gain-to-feed ratios varied by week and treatment. Calves fed HMR had greater gain-to-feed ratio in wk 1; however, increased abnormal fecal days during wk 2 likely reduced feed efficiency. Calves fed HMR were also had lower gain-to-feed ratio during wk 7. No effects of IgG intake were apparent. Sixteen calves had fecal scores greater than 2 (scours) and a trend was observed for more calves on HMR to have scours versus calves on MMR treatment (11 vs. 5; $P<0.07)$. Similarly, more calves on HMR were treated ( $\geq 1$ medical days) compared with calves on MMR (23 vs. $17 ; P<0.04)$.

Trial 2. Calves bedded in DB pens had greater initial serum TP concentrations than calves bedded in CB pens (Table 4). Serum IgG (Figure 5) and TP (Figure 6) were affected by a treatment $\times$ week interaction. Calves

Table 3. Performance (0 to $56 \mathrm{~d}$ ) of calves fed 150 (C150) or 450 (C450) g of IgG in the first $24 \mathrm{~h}$ after birth and 0.68 (MMR) or up to 1.3 $(\mathrm{HMR}) \mathrm{kg} / \mathrm{d}$ of milk replacer (trial 1)

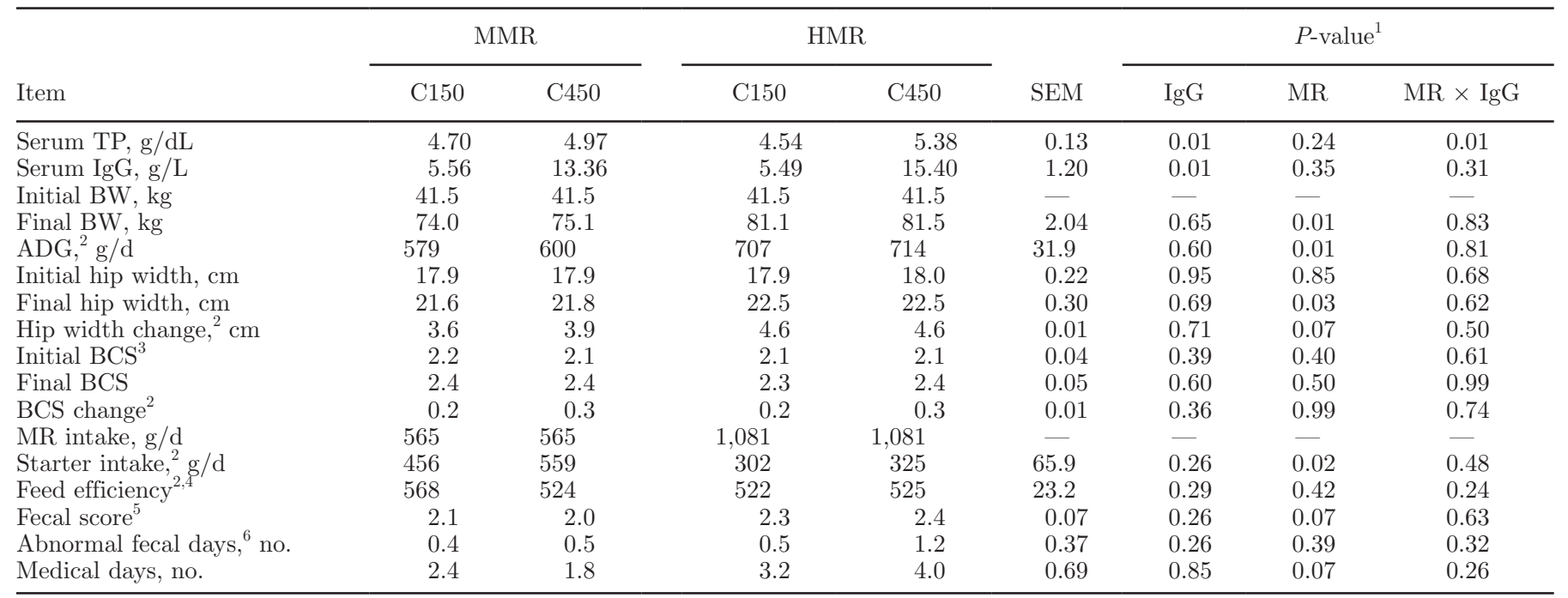

${ }^{1}$ Probability of a significant effect of IgG intake $(\mathrm{IgG}), \mathrm{MR}$ rate $(\mathrm{MR})$, or interaction $(\mathrm{MR} \times \operatorname{IgG})$. Data were covariately adjusted for initial BW.

${ }^{2}$ Significant week $\times$ treatment interaction $(P<0.01)$.

${ }^{3}$ Scored on a 1 to 5 point system with 1 being thin and 5 being obese.

${ }^{4}$ Feed efficiency $(\mathrm{g} / \mathrm{kg})$ was calculated as gain divided by the sum of milk replacer and starter intake.

${ }^{5}$ Feces were scored daily using a 1 to 5 scale with 1 being normal and 5 being watery.

${ }^{6}$ Days with fecal score $>2$. 


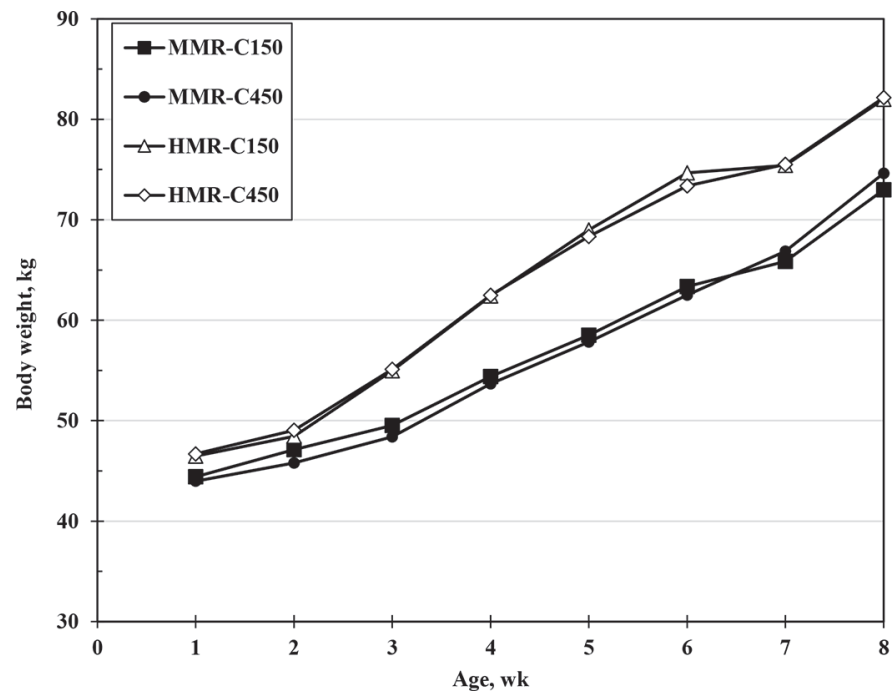

Figure 1. Body weight in calves fed moderate (MMR) or high (HMR) levels of milk replacer before weaning and fed 150 (C150) or 450 (C450) g of IgG from colostrum replacer during the first $24 \mathrm{~h}$ of life in trial 1. Data were covariately adjusted for initial BW. SEM = 1.3 .

fed C450 had fewer days with abnormal fecal scores and tended to have fewer days with medical treatments than calves fed C150 (Table 4). Calves housed in DB pens tended to have lower ADG compared with calves housed in CB pens. There was no mortality during the trial. No significant week $\times$ treatment interactions were identified and other measures of intake and growth were unaffected by treatment.

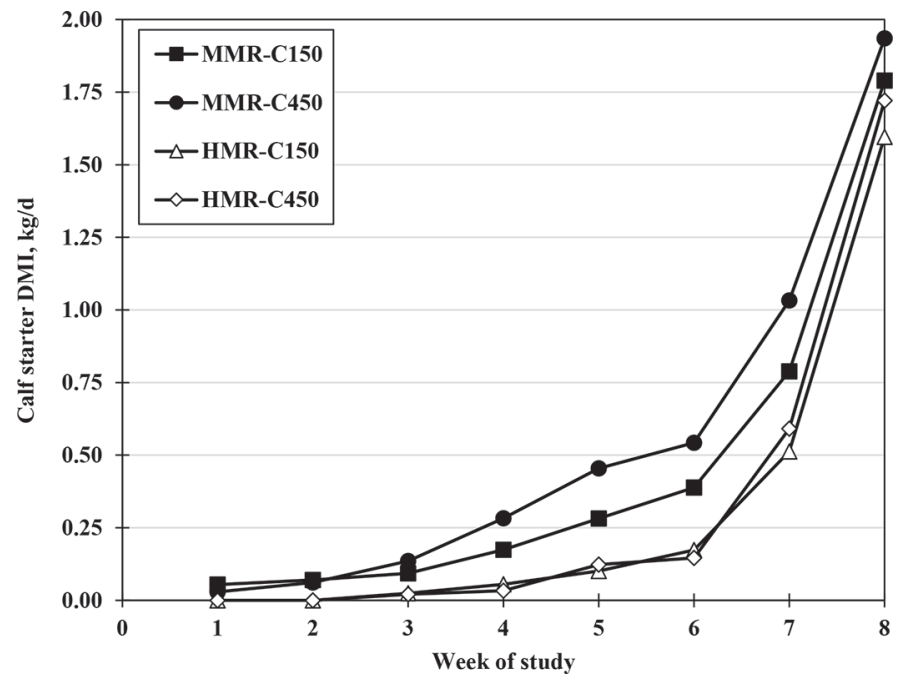

Figure 2. Starter DMI in calves fed moderate (MMR) or high (HMR) levels of milk replacer before weaning and fed 150 (C150) or 450 (C450) g of IgG from colostrum replacer during the first $24 \mathrm{~h}$ of life in trial 1. Data were covariately adjusted for initial BW. SEM = 0.08 .

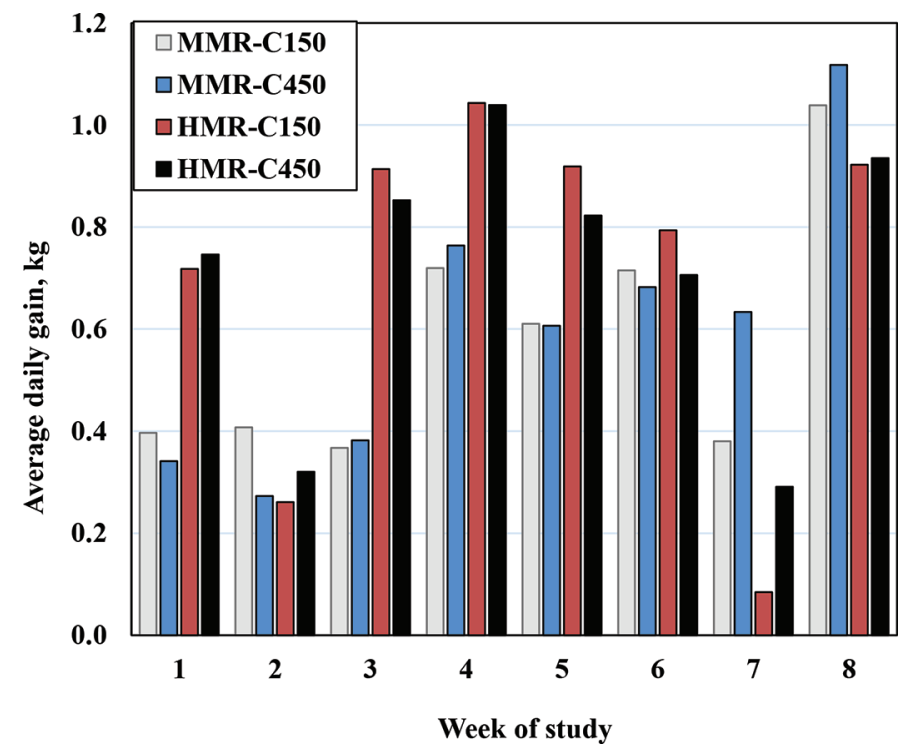

Figure 3. Average daily gain in calves fed moderate (MMR) or high (HMR) levels of milk replacer before weaning and 150 (C150) or 450 (C450) g of IgG from colostrum replacer during the first $24 \mathrm{~h}$ of life in trial 1. Data were covariately adjusted for initial BW. SEM = 0.08. Color version available online.

\section{DISCUSSION}

Serum IgG concentrations and AEA estimates were consistent with multiple feedings of IgG at approximately 1, 6, and $12 \mathrm{~h}$ after birth. Declining AEA with advancing age (Stott et al., 1979; Osaka et al.,

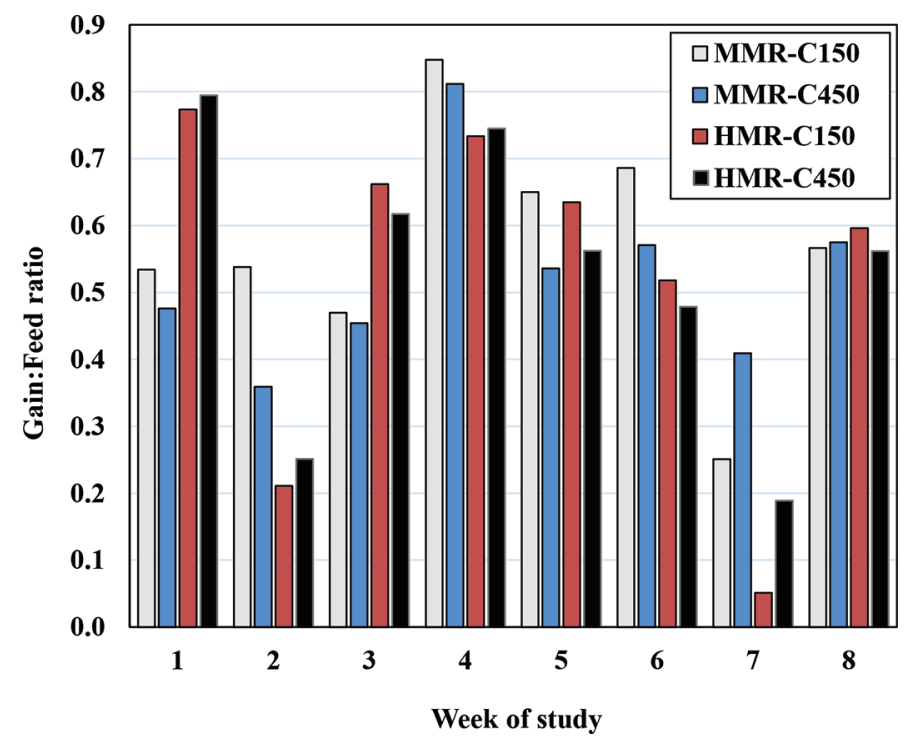

Figure 4. Feed efficiency ( $\mathrm{kg}$ of $\mathrm{ADG} / \mathrm{kg}$ of total DMI) in calves fed moderate (MMR) or high (HMR) levels of milk replacer before weaning and $150(\mathrm{C} 150)$ or $450(\mathrm{C} 450)$ g of IgG from colostrum replacer during the first $24 \mathrm{~h}$ of life in trial $1 . \mathrm{SEM}=0.07$. Color version available online. 
Table 4. Performance (0 to $56 \mathrm{~d}$ ) of calves fed 150 (C150) or 450 (C450) g of IgG in the first $24 \mathrm{~h}$ and bedded in clean (CB) or dirty (DB) pens (trial 2)

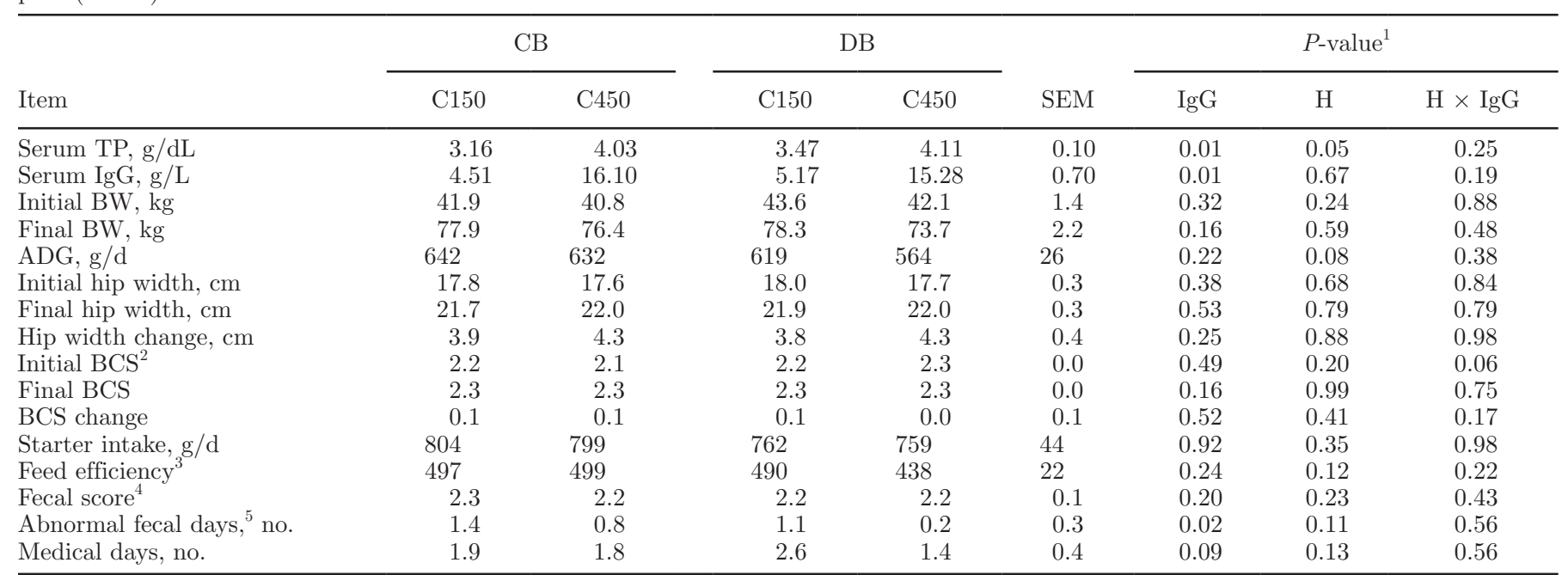

${ }^{1}$ Probability of a significant effect of $\operatorname{IgG}$ intake $(\operatorname{IgG})$, pen hygiene $(\mathrm{H})$, or interaction $(\mathrm{H} \times \operatorname{IgG})$.

${ }^{2}$ Scored on a 1 to 5 point system with 1 being thin and 5 being obese.

${ }^{3}$ Feed efficiency was calculated as gain divided by the sum of milk replacer and starter intake.

${ }^{4}$ Feces were scored daily using a 1 to 5 scale with 1 being normal and 5 being watery.

${ }^{5}$ Days with fecal score $>2$.

2014) likely reduced the amount of IgG absorbed by calves after the first feeding. Therefore, the lower AEA compared with other reports in the literature (Quigley et al., 2002; Foster et al., 2006; Fidler et al., 2011) were expected. Typically, AEA has been reported to be $>20 \%$ when calves are fed one feeding of colostrum within a few hours of birth (Quigley et al., 1998). We expect that serum IgG concentrations would have been higher if calves were fed all IgG in the first feeding.

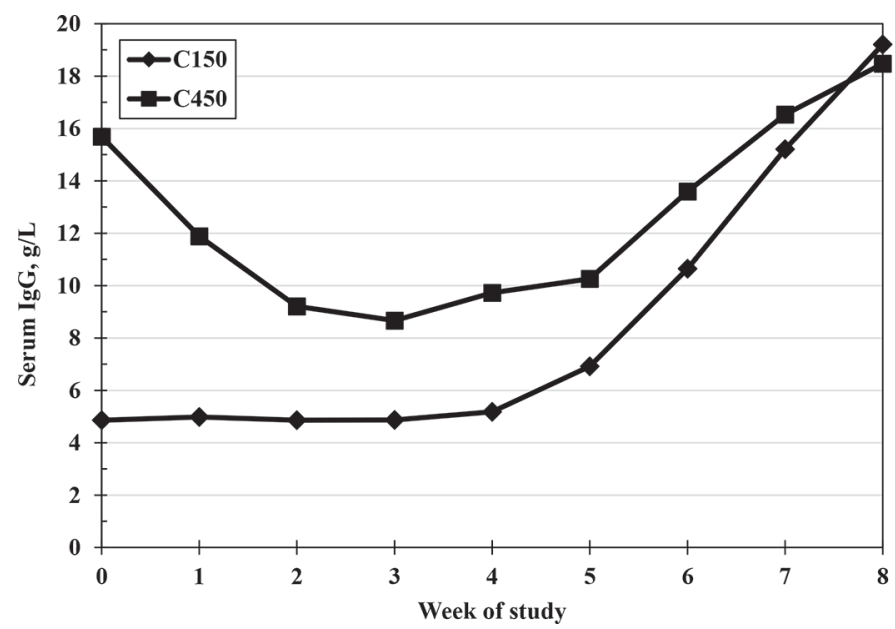

Figure 5. Serum IgG concentration in calves fed 150 (C150) or 450 $(\mathrm{C} 450) \mathrm{g}$ of $\mathrm{IgG}$ in the first 3 feedings after birth in trial 2. SEM $=1.0$.
Serum TP was affected by both treatment and experiment (Table 2). The treatment $\times$ experiment interaction tended to be significant $(P<0.10)$. Calves fed C150 had lower serum TP compared with calves fed C450, which is consistent with greater intakes of protein and $\mathrm{IgG}$. However, the lower serum TP in trial 2 was unexpected. Total protein was measured by the same technicians using the same equipment that was calibrated before use. Therefore, we assume that

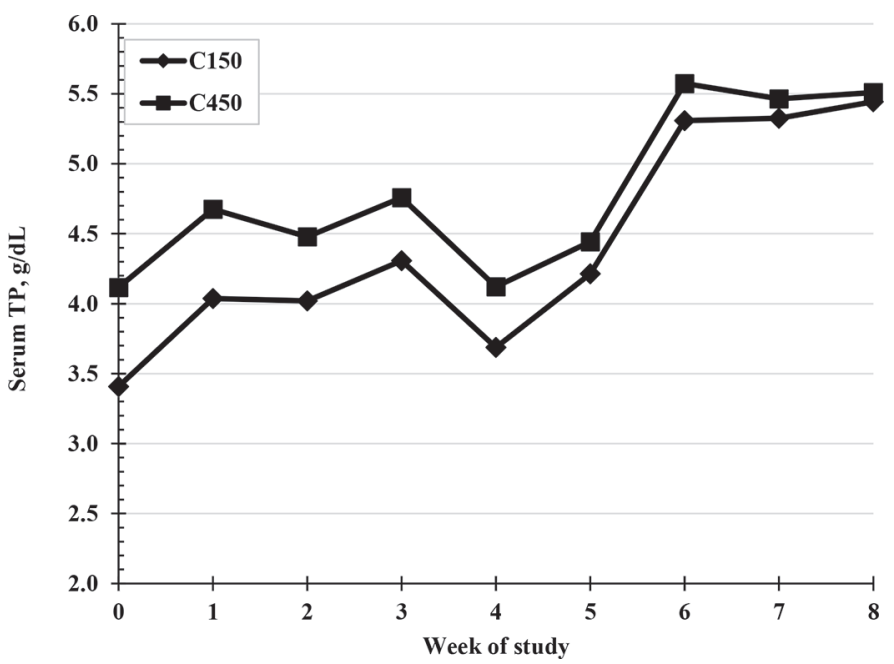

Figure 6. Serum total protein (TP) in calves fed 150 (C150) or 450 (C450) $\mathrm{g}$ of IgG in the first 3 feedings after birth, trial 2. SEM $=0.08$. 
differences were due to conditions of the experiment. We hypothesize that lower serum TP might have been due to differences in environment during the 2 trials. Average temperatures, measured at a weather station approximately $10 \mathrm{~km}$ from the experimental site, were $14^{\circ} \mathrm{C}$ and $7^{\circ} \mathrm{C}$ when calves were collected for trials 1 and 2 , respectively. It is possible that the greater energy demand in trial 2 caused calves to utilize non-IgG protein to support maintenance energy demands and thereby reduce serum TP concentrations. Serum IgG concentrations may have been less extensively catabolized to meet maintenance energy due to endothelial neonatal Fc receptors, which effectively protect circulating IgG from degradation and extend half-life (Roopenian and Akilesh, 2007). However, the supposition that protein was catabolized to support maintenance energy requirements awaits further investigation.

Calves fed HMR in trial 1 were larger at initiation of the study, although they were assigned randomly to treatment (Table 3). To reduce effects of initial BW, data were reanalyzed using initial $\mathrm{BW}$ as a covariate. However, differences in performance between calves fed MMR and HMR were consistent with other studies (Chapman et al., 2016; Hill et al., 2016) in that calves fed HMR grew faster, had greater fecal scores and more days treated, ate less starter, and were less efficient postweaning than calves fed MMR. Lower gain-to-feed ratio in calves fed HMR may be due to poor feed efficiency during wk 2 (scours) and wk 7 (immediately postweaning). In total, 16 calves had fecal scores $>2$ (scours) and a trend was observed for more calves on HMR to have scours than calves on MMR (11 vs. 5; $P$ $<0.07)$. Similarly, more calves on HMR were treated ( $\geq 1$ medical days) compared with calves on MMR (23 vs. $17 ; P<0.04)$.

The difference in feed efficiency between MMR and HMR calves in our study was unexpected. Calves fed HMR used nutrients less efficiently during wk 2 and 7 , but were more efficient during wk 1 and 3. Nutrients in MR are typically more digestible and are used with greater efficiency than nutrients in starter. Other studies (Diaz et al., 2001; Khan et al., 2007b; Chapman et al., 2017) reported greater feed efficiency in calves fed more milk or MR. However, other studies (Khan et al., 2007a) reported no difference in feed efficiency in calves fed more milk before weaning. Differences in calf health may have contributed to lower efficiency in HMR calves.

Calves fed MMR consumed more starter from an earlier age than calves fed HMR. However, calves fed MMR-C450 began consuming calf starter at an earlier age than other calves (Figure 2), which may have manifested in improved ADG and feed efficiency in wk 7, immediately postweaning.
Calves consuming greater amounts of starter may have greater amounts of undigested feed residues that are included when live BW is measured ("gut fill"). Thus, calves fed MMR could have had less BW than was measured in trial 1 if gut fill had been excluded. The amount of undigested residue was not determined in this study. However, because starter contained little NDF and $>40 \%$ starch, we expect that the contributions of undigested feed residue to live BW measurements were minimal. Most data suggest that gut fill is primarily associated with NDF (i.e., forage) intake (Stobo et al., 1966; Terré et al., 2013).

Colostrum ingestion is essential not only for absorption of immunoglobulins, leukocytes, and other immune components, but also for maturation of the intestine (Blättler et al., 2001; Sauter et al., 2004; Yang et al., 2015) and development of the active immune response (Yang et al., 2015). In the current study, calves consumed $500(\mathrm{C} 150)$ or 1,500 (C450) g of colostrum replacer, which was composed of spray-dried, defatted bovine colostrum, dry fat, dried whey, vitamins, minerals, and additives. We did not attempt to quantify the amounts or types of bioactive components in the colostrum replacer.

Yang et al. (2015) attributed greater BW gain to $8 \mathrm{~d}$ of age in calves fed colostrum to a greater concentration of bioactive compounds compared with transition milk or bulk tank milk. In the study by Yang et al. (2015), calves gained $2.2,1.7$, and $-0.4 \mathrm{~kg}$, respectively, to $8 \mathrm{~d}$ of age. Differences in BW change may have been due to increased incidence of diarrhea in calves $(0,1$, and 5 animals, respectively). We recorded no differences in BW gain between calves fed C150 and C450 in either trial. Mean BW gains during the first week of the trial were 0.56 and $0.55 \mathrm{~kg} / \mathrm{d}$ in trial 1 and 0.25 and 0.25 $\mathrm{kg} / \mathrm{d}$ in trial 2 for calves fed $\mathrm{C} 150$ and C450, respectively.

In trial 2, calves were housed in pens containing either fresh or soiled straw to impose differential stressors on the animals. Generally, pen cleanliness had minimal effects on animal performance, although calves housed on clean bedding tended to grow faster.

Serum was collected weekly for measurement of IgG (Figure 5) and TP (Figure 6). Changes in IgG concentration differed markedly by colostrum feeding treatment without an effect of pen cleanliness. Serum IgG in calves fed C450 declined from peak concentration at 2 to $3 \mathrm{~d}$ of age (wk 0 ) to a nadir at $3 \mathrm{wk}$; thereafter, concentrations increased gradually to the end of the study at 8 wk. Conversely, serum IgG in calves fed C150 changed little from 0 to $4 \mathrm{wk}$, at about $5 \mathrm{~g}$ of $\mathrm{IgG} / \mathrm{L}$ of serum. From wk 4, concentrations also increased to wk 8. By $7 \mathrm{wk}$, there were few differences between the 2 groups, suggesting that all calves were 
producing antibody because of development of the active immune system.

Murphy et al. (2014) used a nonlinear regression with a one-phase exponential decay model to predict the half-life of IgG derived from colostrum, a colostrumderived colostrum replacer product, or plasma IgG administered intravenously. They reported that the halflife of $\operatorname{IgG}$ from colostrum (28.5 d) was longer than that of IgG from the replacer (19.1 d) or plasma-transfused $\operatorname{IgG}(27.3 \mathrm{~d})$. Plasma IgG concentrations at $\mathrm{d} 1$ were 23.8, 23.1, and $6.7 \mathrm{~g} / \mathrm{L}$, respectively. These data are similar to those of the C450 calves in our study, in that serum IgG declined to approximately $3 \mathrm{wk}$. The calculated half-life of serum IgG in calves fed C450 from 0 to 3 wk was $23.9 \mathrm{~d}$, which is similar to that reported by Murphy et al. (2014). However, serum IgG in our calves began to increase from 4 wk to the end of the study at $8 \mathrm{wk}$, suggesting that de novo synthesis of $\operatorname{IgG}$ exceeded decay of maternal concentrations. Increasing serum IgG from 4 to 8 wk differs from the observations of Murphy et al. (2014).

Hassig et al. (2007) used an antibody marker to feline antigen fed in colostrum to calves as an indicator of circulating maternal antibody decay from 2 to $182 \mathrm{~d}$ of age. Those authors reported that total serum IgG concentrations declined from approximately $26 \mathrm{~g} / \mathrm{L}$ at $2 \mathrm{~d}$ of age to approximately $10 \mathrm{~g} / \mathrm{L}$ by 5 wk of age. Partitioning total serum IgG to maternal (colostral) and endogenous fractions indicated that maternal IgG declined throughout the 182-d period with a half-life of 10.1 d. Endogenous IgG production began early in life and by approximately $6 \mathrm{wk}$, most circulating IgG was endogenously derived.

Nonnecke et al. (2012) reported increases in serum $\mathrm{IgG}_{1}$ and $\mathrm{IgG}_{2}$ concentrations in colostrum-deprived calves from undetectable levels in the first week of life to levels similar to those in calves fed colostrum by the end of the 7 -wk study. Also, serum $\operatorname{IgG}_{1}$ concentrations in calves fed $3.8 \mathrm{~L}$ of maternal colostrum declined linearly throughout the study, whereas serum $\mathrm{IgG}_{2}$ concentrations declined to $2 \mathrm{wk}$ of age and then increased to the end of the study.

Published data generally support the concept that serum IgG concentrations greater than about $10 \mathrm{~g} / \mathrm{L}$ reduce the risk of disease in neonatal calves. For example, Faber et al. (2005) reported that feeding $4 \mathrm{~L}$ of maternal colostrum reduced veterinary costs, increased BW gain, and improved first-lactation milk production in Brown Swiss calves compared with calves fed $2 \mathrm{~L}$ of colostrum. On the other hand, Bateman et al. (2012) reported only a moderate effect of abnormal fecal scores on growth through 8 wk of age in studies conducted at the same facility. Other factors such as starter and liquid intake affected growth more significantly. However, excellent management and low rates of neonatal morbidity and mortality in studies evaluated by Bateman et al. (2012) and in the current experiments likely reduced the risk associated with lower serum IgG or TP concentrations.

Our data suggest that lower serum IgG concentrations in calves fed less IgG may not dramatically influence growth, although calves fed C450 ate more starter in trial 1 and had fewer scour days in trial 2 . We conclude that both passive immunity and management must be considered when evaluating susceptibility of calves to disease.

\section{ACKNOWLEDGMENTS}

The authors gratefully acknowledge the assistance of W. Hu for statistical analysis and T. Dennis and X. Suarez for review of the manuscript. Funding for this research was provided by Provimi.

\section{REFERENCES}

AOAC International. 2000. Official Methods of Analysis. Vol. I. 17th ed. AOAC International, Arlington, VA.

Bateman, H. G., II, T. M. Hill, J. M. Aldrich, R. L. Schlotterbeck, and J. L. Firkins. 2012. Meta-analysis of the effect of initial serum protein concentration and empirical prediction model for growth of neonatal Holstein calves through 8 weeks of age. J. Dairy Sci. 95:363-369.

Blättler, U., H. M. Hammon, C. Morel, C. Philipona, A. Rauprich, V. Romé, I. Le Huërou-Luron, P. Guilloteau, and J. W. Blum. 2001. Feeding colostrum, its composition and feeding duration variably modify proliferation and morphology of the intestine and digestive enzyme activities of neonatal calves. J. Nutr. 131:1256-1263.

Chapman, C. E., P. S. Erickson, J. D. Quigley, T. M. Hill, H. G. Bateman 2nd, F. X. Suarez-Mena, and R. L. Schlotterbeck. 2016. Effect of milk replacer program on calf performance and digestion of nutrients with age of the dairy calf. J. Dairy Sci. 99:2740-2747.

Chapman, C. E., T. M. Hill, D. R. Elder, and P. S. Erickson. 2017. Nitrogen utilization, preweaning nutrient digestibility, and growth effects of Holstein dairy calves fed 2 amounts of a moderately high protein or conventional milk replacer. J. Dairy Sci. 100:279-292.

Cobb, C. J., B. S. Obeidat, M. D. Sellers, A. R. Pepper-Yowell, and M. A. Ballou. 2014. Group housing of Holstein calves in a poor indoor environment increases respiratory disease but does not influence performance or leukocyte responses. J. Dairy Sci. 97:3099-3109.

Diaz, M. C., M. E. Van Amburgh, J. M. Smith, J. M. Kelsey, and E. L. Hutten. 2001. Composition of growth of Holstein calves fed milk replacer from birth to 105-kilogram body weight. J. Dairy Sci. 84:830-842.

Donovan, G. A., I. R. Dohoo, D. M. Montgomery, and F. L. Bennett. 1998. Associations between passive immunity and morbidity and mortality in dairy heifers in Florida, USA. Prev. Vet. Med. $34: 31-46$.

Faber, S. N., N. E. Faber, T. C. McCauley, and R. L. Axemail. 2005. Case Study: Effects of colostrum ingestion on lactational performance. Prof. Anim. Sci. 21:420-425.

FASS. 2010. Guide for the Care and Use of Agricultural Animals in Research and Teaching. 3rd ed. Federation of Animal Science Societies (FASS), Savoy, IL.

Fidler, A. P., M. L. Alley, and G. W. Smith. 2011. Serum immunoglobulin $\mathrm{G}$ and total protein concentrations in dairy calves fed a colostrum-replacement product. J. Dairy Sci. 94:3609-3612.

Foster, D. M., G. W. Smith, T. R. Sanner, and G. V. Busso. 2006. Serum IgG and total protein concentrations in dairy calves fed 
two colostrum replacement products. J. Am. Vet. Med. Assoc. 229:1282-1285.

Frank, N. A., and J. B. Kaneene. 1993. Management risk factors associated with calf diarrhea in Michigan dairy herds. J. Dairy Sci. 76:1313-1323.

Gulliksen, S. M., E. Jor, K. I. Lie, I. S. Hamnes, T. Løken, J. Åkerstedt, and O. Østerås. 2009. Enteropathogens and risk factors for diarrhea in Norwegian dairy calves. J. Dairy Sci. 92:5057-5066

Hassig, M., T. Stadler, and H. Lutz. 2007. Transition from maternal to endogenous antibodies in newborn calves. Vet. Rec. 160:234-235.

Heinrichs, A. J., and B. S. Heinrichs. 2011. A prospective study of calf factors affecting first-lactation and lifetime milk production and age of cows when removed from the herd. J. Dairy Sci. 94:336-341.

Hill, T. M., J. M. Aldrich, R. L. Schlotterbeck, and H. G. Bateman II. 2006. Effects of feeding calves different rates and protein concentrations of twenty percent fat milk replacers on growth during the neonatal period. Prof. Anim. Sci. 22:252-260.

Hill, T. M. H. G. Bateman II, J. M. Aldrich, and R. L. Schlotterbeck. 2011. Comparisons of housing, bedding, and cooling options for dairy calves. J. Dairy Sci. 94:2138-2146.

Hill, T. M., J. D. Quigley, F. X. Suarez-Mena, H. G. Bateman II, and R. L. Schlotterbeck. 2016. Effect of milk replacer feeding rate and functional fatty acids on dairy calf performance and digestion of nutrients. J. Dairy Sci. 99:6352-6361.

Jones, C. M., R. E. James, J. D. Quigley III, and M. L. McGilliard. 2004. Influence of pooled colostrum or colostrum replacement on IgG and evaluation of animal plasma in milk replacer. J. Dairy Sci. 87:1806-1814.

Kertz, A. F., and H. Chester-Jones. 2004. Invited Review: Guidelines for measuring and reporting calf and heifer experimental data. J. Dairy Sci. 87:3577-3580.

Khan, M. A., D. M. Weary, and M. A. von Keyserlingk. 2011. Invited review: Effects of milk ration on solid feed intake, weaning, and performance in dairy heifers. J. Dairy Sci. 94:1071-1081.

Khan, M. A., H. J. Lee, W. S. Lee, H. S. Kim, K. S. Ki, T. Y. Hur, G. H. Suh, S. J. Kang, and Y. J. Choi. 2007a. Structural growth, rumen development, and metabolic and immune responses of Holstein male calves fed milk through step-down and conventional methods. J. Dairy Sci. 90:3376-3387.

Khan, M. A., H. J. Lee, W. S. Lee, H. S. Kim, S. B. Kim, K. S. Ki, J. K. Ha, H. G. Lee, and Y. J. Choi. 2007b. Pre- and postweaning performance of Holstein female calves fed milk through step-down and conventional methods. J. Dairy Sci. 90:876-885.

Murphy, J. M., J. V. Hagey, and M. Chigerwe. 2014. Comparison of serum immunoglobulin $\mathrm{G}$ half-life in dairy calves fed colostrum, colostrum replacer or administered with intravenous bovine plasma. Vet. Immunol. Immunopathol. 158:233-237.

Nonnecke, B. J., W. R. Waters, J. P. Goff, and M. R. Foote. 2012. Adaptive immunity in the colostrum-deprived calf: Response to early vaccination with Mycobacterium bovis strain bacille Calmette Guerin and ovalbumin. J. Dairy Sci. 95:221-239.

Osaka, I., Y. Matsui, and F. Terada. 2014. Effect of the mass of immunoglobulin (Ig)G intake and age at first colostrum feeding on serum IgG concentration in Holstein calves. J. Dairy Sci. 97:66086612 .

Quigley, J. D., III, J. J. Drewry, and K. R. Martin. 1998. Estimation of plasma volume in Holstein and Jersey calves. J. Dairy Sci. 81:1308-1312.

Quigley, J. D., III, C. J. Kost, and T. M. Wolfe. 2002. Absorption of protein and IgG in calves fed a colostrum supplement or replacer. J. Dairy Sci. 85:1243-1248.

Quigley, J. D., III, T. A. Wolfe, and T. H. Elsasser. 2006. Effects of additional milk replacer feeding on calf health, growth, and selected blood metabolites in calves. J. Dairy Sci. 89:207-216.

Robertson, J. B., and P. J. Van Soest. 1981. The Detergent System of Analysis and its Application to Human Foods. Cornell University, Ithaca, NY

Roopenian, D. C., and S. Akilesh. 2007. FcRn: The neonatal Fc receptor comes of age. Nat. Rev. Immunol. 7:715-725.

Sauter, S. N., B. Roffler, C. Philipona, C. Morel, V. Romé, P. Guilloteau, J. W. Blum, and H. M. Hammon. 2004. Intestinal development in neonatal calves: Effects of glucocorticoids and dependence on colostrum feeding. Biol. Neonate 85:94-104.

Soberon, F., E. Raffrenato, R. W. Everett, and M. E. Van Amburgh. 2012. Preweaning milk replacer intake and effects on long-term productivity of dairy calves. J. Dairy Sci. 95:783-793.

Stilwell, G., and R. C. Carvalho. 2011. Clinical outcome of calves with failure of passive transfer as diagnosed by a commercially available IgG quick test kit. Can. Vet. J. 52:524-526.

Stobo, I. J. F., J. H. B. Roy, and H. J. Gaston. 1966. Rumen development in the calf. 1. The effect of diets containing different proportions of concentrates to hay on rumen development. Br. J. Nutr. 20:171-188.

Stott, G. H., D. B. Marx, B. E. Menefee, and G. T. Nightengale. 1979. Colostral immunoglobulin transfer in calves. I. Period of absorption. J. Dairy Sci. 62:1632-1638.

Swan, H., S. Godden, R. Bey, S. Wells, J. Fetrow, and H. ChesterJones. 2007. Passive transfer of immunoglobulin G and preweaning health in Holstein calves fed a commercial colostrum replacer. J. Dairy Sci. 90:3857-3866

Terré, M., E. Pedrals, A. Dalmau, and A. Bach. 2013. What do preweaned and weaned calves need in the diet: A high fiber content or a forage source? J. Dairy Sci. 96:5217-5225.

Van Soest, P. J., J. B. Robertson, and B. A. Lewis. 1991. Methods for dietary fiber, neutral detergent fiber, non-starch polysaccharides in relation to animal nutrition. J. Dairy Sci. 74:3583-3597.

Weaver, D. M., J. W. Tyler, D. C. VanMetre, D. E. Hostetler, and G. M. Barrington. 2000. Passive transfer of colostral immunoglobulins in calves. J. Vet. Intern. Med. 14:569-577.

Wildman, E. E., G. M. Jones, P. E. Wagner, R. L. Bowman, H. F. Troutt Jr., and T. N. Lesch. 1982. A dairy cow body condition scoring system and its relationship to selected production characteristic. J. Dairy Sci. 65:495-501.

Yang, M., Y. Zou, Z. H. Wu, S. L. Li, and Z. J. Cao. 2015. Colostrum quality affects immune system establishment and intestinal development of neonatal calves. J. Dairy Sci. 98:7153-7163. 